\title{
Comparison of Cadmium Accumulation in Upright and Leaning Poplar Trees
}

\author{
Gong Rong, ${ }^{a}$ Yin Chu, ${ }^{\mathrm{b}, *}$ Shengquan Liu, ${ }^{\mathrm{a}, *}$ Lakchai Kataweteetham, ${ }^{\mathrm{b}}$ and Jiang Zhu ${ }^{\mathrm{b}}$
}

Poplar 69 (Populus deltoides Bartr. cv. 'Lux' (I-69/55)) was chosen for a pot experiment to study the growth and the extraction of $\mathrm{Cd}$ from soil to various parts of the one-year-old trees growing in upright and artificial leaning $\left(45^{\circ}\right)$ patterns under different Cd stress. The results indicated considerable tolerance of both upright poplar (UP) and leaning poplar (LP) to $\mathrm{Cd}$ stress in the soil, though with significant inhibition from $\mathrm{Cd}$ application. LP demonstrated significantly lower height and basal diameter growth than UP. Cd concentrations in different parts of both UP and LP increased with the increase of $\mathrm{Cd}$ in the soil and it followed a general order as Bark > Leaf > Root > Stem. Different parts of poplar had average bioconcentration factor (BCF) ranges between 0.08 to 2.36, and average translocation factor (TF) between 0.67 to 7.92 , indicating a big difference of phytoextraction ability among the parts, among the treatments, and between LP and UP. Average Cd concentration, BCF, and TF for each part of LP were higher than that of UP, but the difference was not significant. Significantly higher Cd concentration was found in the tension zone of stem wood than that in the opposite zone for LP.

Keywords: Cd; Phytoextraction; Poplar 69; Upright growth; Leaning growth; Dendroremediation

Contact information: a: School of Forestry \& Landscape Architecture, Anhui Agricultural University, Hefei, 230036, PR China; b: School of Resources and Environment, Anhui Agricultural University, Hefei, 230036, PR China; *Corresponding authors: chuyin@ahau.edu.cn; liusq@ahau.edu.cn

\section{INTRODUCTION}

With rapid industrialization, heavy metal pollution has become a serious threat to the environment in many countries (González-Oreja et al. 2008; Zhang et al. 2018). The heavy metal cadmium enters the environment through mining and smelting of metalliferous ores, industrial processes, heating systems, urban transportation, and phosphate fertilizer, and is considered one of the most prevalent toxic pollutants to plants, animals, and human beings (Mclaughlin et al. 1999; Han et al. 2002; Escarré et al. 2011; Mahar et al. 2016). Unlike organic matter, heavy metals are inherently non-biodegradable, and thus they can only be removed from the environment through physical, chemical, or biological methods or be limited from transport by immobilization using chemical or microbiological methods (Ali et al. 2013).

Phytoremediation, the use of plants to remove pollutants from the environment or make them stabilized or less toxic, has increasingly been examined as a practical, costeffective, and eco-friendly technology (Pulford and Watson 2003; Li et al. 2012). Dendroremediation, the use of trees in phytoremediation, is of great potential for the phytoextraction and phytostabilization of heavy metal polluted soil, because of their specific characteristics such as fast rate of growth, the ability to grow on nutrient-poor soil, and deep root system (González-Oreja et al. 2008; Zeng et al. 2019).

Poplar, one of the most cultivated fast-growing species in the world, is easy to breed and has strong adaptability. Though inferior to some herbaceous plants with hyperaccumulation ability, such as Thlaspi caerulescens and Arabidopsis halleri, poplar demonstrates relatively good phytoextraction ability of heavy metals (Zhuang et al. 2007; 
Fuksová et al. 2009; Antony et al. 2012; Pilipović et al. 2019; Kataweteetham et al. 2020). With the deep root system and a great amount of leaf mass, the poplar tree has strong transpiration and is an excellent drawer of water and elements from the whole profile of the soil. The wood and bark of poplar are supposed to be important sinks for heavy metals, where heavy metals are accumulated and immobilized with additional tissue being formed each growing season (Pulford and Watson 2003). From the perspective of wood utilization, heavy metal enriched wood also contributes to the improvement of some wood properties. Moreover, poplar's complete genome facilitates the later regulation of gene expression to improve the formation of poplar heavy metal-enriched wood and the ability of wood to accumulate heavy metals (Parrotta et al. 2015; Romè et al. 2015). Therefore, planting poplar is considered as a green and efficient heavy metal pollution control technology with the most potential and application prospects in the future (Azzarello et al. 2011; Thakur et al. 2016).

Tension wood is an abnormal wood tissue of a trunk or branch of a broad-leaved tree that is formed via inclining plantation and whose anatomical and physicomechanical properties are formed in an attempt to restore it to its original position while being bended under external forces (Fisher and Stevenson 1981; Archer 1987). The structure of tension wood of poplar is quite different from its normal wood. Tension wood has one more layer in the secondary cell wall layer, which is a gelatinous layer with high content of cellulose, regularly arranged with the angle close to zero, leaving plenty of micro spaces (10 to 30 $\mathrm{nm}$ ) among the microfibril bundles (Fang et al. 2008; Liu and Liu 2011; Chang et al. 2015). These micropores could be the proper sites for the absorption and accumulation of heavy metal ions. Therefore, in the transpiration process, inorganic salts would be easily transported through the vessels of tension wood from roots to tree crowns and the gelatinous layer is supposed to help the enrichment of heavy metals in wood tissue. With the special structural characters of tension wood, it should be interesting to study the dendroremediation of leaning growing trees. However, no such study has ever been conducted.

In this study, the authors compared the one-year-old upright growing and leaning growing poplars through pot experiments in their growth, $\mathrm{Cd}$ accumulation in different parts of trees, and their extraction ability.

\section{EXPERIMENTAL}

\section{Materials}

The experiment was conducted in the experimental yard of Anhui Agricultural University, Hefei, China $\left(117^{\circ} 14^{\prime} 46^{\prime \prime} \mathrm{E}, 31^{\circ} 51^{\prime} 52^{\prime \prime N}\right)$. The soil used in this experiment was a mixture of local topsoil and organic nutrient soil, with the mixing ratio being 1:1. The soil $\mathrm{pH}$ of the mixture was 6.91 , and the contents of organic matter, available $\mathrm{N}$, available $\mathrm{P}$, available $\mathrm{K}$, and available $\mathrm{S}$, were $73.10 \mathrm{~g} / \mathrm{kg}, 1.82 \mathrm{~g} / \mathrm{kg}, 133.8 \mathrm{mg} / \mathrm{kg}, 346 \mathrm{mg} / \mathrm{kg}$, and $80.9 \mathrm{mg} / \mathrm{kg}$, respectively. The soil nutrients were well-balanced and can meet the requirement of poplar growth. The background contents of heavy metals $\mathrm{Cd}, \mathrm{Cu}$, and $\mathrm{Zn}$ were $0.15,22.68$, and $37.43 \mathrm{mg} / \mathrm{kg}$, respectively, much lower than the risk screening standards for agricultural land as per GB 15618 (2018) and were similar as the background values of the elements in this region (CNEMC and SEPA 1990; GB 15618 2018).

\section{Plantation and Cd treatments}

Branch cuttings from the new branches of naturally growing poplar 69 trees (Populus deltoides Bartr. cv. 'Lux' (I-69/55)) in an experimental forest near the university campus were used in the experiment. This clone was originally introduced from Italy to China about 40 
years ago. Thirty cuttings with $15 \mathrm{~cm}$ in length and in good and uniform growth conditions were planted in 30 pots in March 2018. The size of each pot was $33 \mathrm{~cm}$ in diameter and 38 $\mathrm{cm}$ in height. After 2 months of natural growth, $\mathrm{Cd}\left(\mathrm{NO}_{3}\right)_{2}$ solution was applied to each pot according to the pre-designed concentrations of $\mathrm{Cd}$. A total of four treatments were included, which were $5,20,50$, and $100 \mathrm{mg} / \mathrm{kg}$, namely $\mathrm{C} 1, \mathrm{C} 2, \mathrm{C} 3$, and $\mathrm{C} 4$, respectively, plus the control group $\mathrm{C} 0$, where no extra $\mathrm{Cd}$ was added. For each treatment, the authors also set two growth patterns, i.e., normal upright growth and artificial leaning $\left(45^{\circ}\right)$ growth. Three repetitions were set for every $\mathrm{Cd}$ treatment and growth pattern. In the beginning, the pots were placed in a greenhouse where the sunshine and ventilation were both not good. Therefore, the saplings grew slowly during the period from March to June. At the beginning of July, the pots were moved to a well-lit and well-ventilated place with a transparent cover to avoid the influence of a rainstorm. The pots of artificial leaning groups were then set inclined by $45^{\circ}$ angle and each sapling was fixed by a bamboo pole. The pots were placed in a random distribution to avoid the influence of the position. The experimental location was far from the industrial district and traffic highway, where the influence of air pollution was negligible.

\section{Measurement and management}

Monthly measurements of poplar tree growth in terms of height and basal diameter were taken from August to November at the end of each month. The height of the tree was measured from the part near the soil surface in the pot to the top of the tree. The circumference was measured on the trunk at the height $5 \mathrm{~cm}$ from the soil surface in the pot with a measuring tape, whereby the basal diameter was calculated. The poplars were watered depending on their needs and evenly for each pot, about every other day during the summertime, and to avoid over-watering and $\mathrm{Cd}$ leaching.

\section{Sampling, pretreatment, and analysis}

The harvest of the 30 pots of both upright poplar (UP) and leaning poplar (LP) under all five treatments took place at the beginning of December. However, leaf samples were collected before the leaves began to fall in November. Then, in the harvest, the whole tree was pulled out to sample the root, stem, and bark. No branches grew out for the one-year-old poplar trees. The trunk was sampled at three heights, i.e., the basal, middle, and top parts along the trunk, for stem wood and bark. For the trunk of LP, also at the three heights, stem and bark samples were taken in the two zones, i.e., the tension zone (TZ), which is located at the upper part of the trunk of LP, and the opposite zone (OZ), which is located at the lower part of the trunk of LP.

Root samples were first rinsed with tap water to get rid of the attached soil, and then all tree samples were rinsed three times with deionized water. All rinsed tree samples of root, stem, bark, and leaf were oven-dried at $60{ }^{\circ} \mathrm{C}$ for approximately $24 \mathrm{~h}$ to constant weight. The temperature was set to this value to prevent $\mathrm{Cd}$ volatilizing at higher temperatures. The dried samples were ground to obtain a homogeneous powder with a metal-free mill and stored in sealed plastic bags until analysis.

Metal concentrations of $\mathrm{Cd}$ in plant samples were determined by graphite furnace atomic absorption spectrophotometer (TAS990 GF, Beijing PERSEE General Instrument Co. Ltd, Beijing, China).

\section{Calculation and data processing}

Bio-concentration factor (BCF) and translocation factor (TF) are the factors to determine the translocation ability of plants to accumulate heavy metals or metalloids ( $\mathrm{Wu}$ et al. 2010). The BCF was calculated as the ratio of the heavy metal/metalloid concentration in plant tissues to that in the soil, i.e., Eq. 1, 


$$
\mathrm{BCF}=C_{\text {plant tissue }} / C_{\text {soil }}
$$

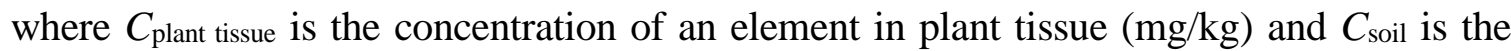
concentration of the element in the soil $(\mathrm{mg} / \mathrm{kg})$.

The TF was calculated as the ratio of an element concentration in the plant's aerial part to that in the plant root, as Eq. 2,

$$
\mathrm{TF}=C_{\text {aerial part }} / C_{\text {root }}
$$

where $\mathrm{C}_{\text {aerial part }}$ is the concentration of an element in plant's aerial part $(\mathrm{mg} / \mathrm{kg})$ and $\mathrm{C}_{\text {root }}$ is the concentration of the element in plant's root $(\mathrm{mg} / \mathrm{kg})$.

All data calculations and tables were performed in Excel 2013 (Microsoft, Redmond, Washington, USA), and figures were drawn using Origin Pro2017 (Originlap, 2017, Northampton, Massachusetts, USA). Multi-way analysis of variance (ANOVA) and the least significant difference test was applied to identify significant differences between the means in SPSS 19.0 (IBM, Armonk, New York, USA).

\section{RESULTS AND DISCUSSION}

\section{Poplar Growth}

No visual phytotoxicity symptoms, such as necrotic spots on leaves, were observed on the poplar trees during the whole growing period and at harvest. Tree heights and basal diameters of both UP and LP at all treatments increased with time, indicating that poplar trees in both upright and leaning growth patterns can grow under Cd stress.

The height and basal diameter of poplar trees were significantly influenced by $\mathrm{Cd}$ addition, with that in the control group ( $\mathrm{C} 0$ ) being higher than other treatments at harvest (in December) for both UP and LP (Fig. 1 (a) and (b)), with the exception of the basal diameter of LP at $\mathrm{C} 1$. The result indicated the inhibition of tree growth by $\mathrm{Cd}$ stress in the soil, which is consistent with the findings described by Wang and Jia (2010). The heights of UP at harvest at $\mathrm{C} 1, \mathrm{C} 2, \mathrm{C} 3$, and $\mathrm{C} 4$ were decreased $15.53 \%, 16.35 \%, 12.22 \%$, and $8.07 \%$ compared to that at C0, respectively, while that of LP decreased $10.71 \%, 20.53 \%$, $23.44 \%$, and $10.04 \%$, respectively.

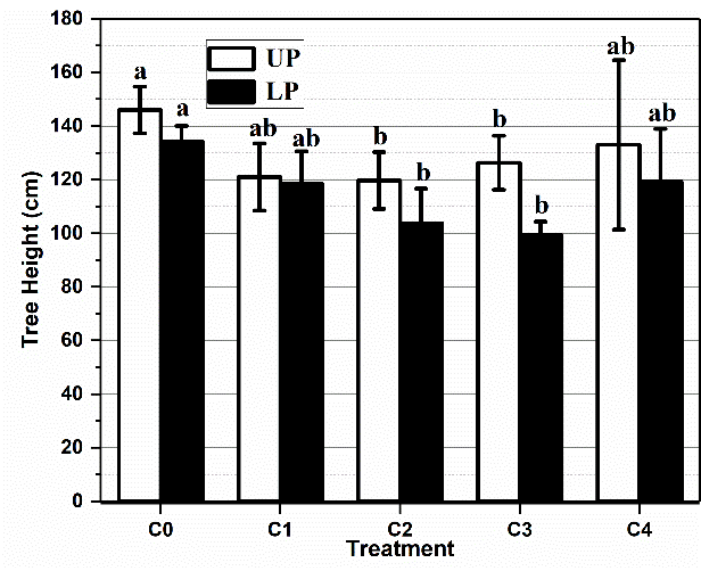

(a)

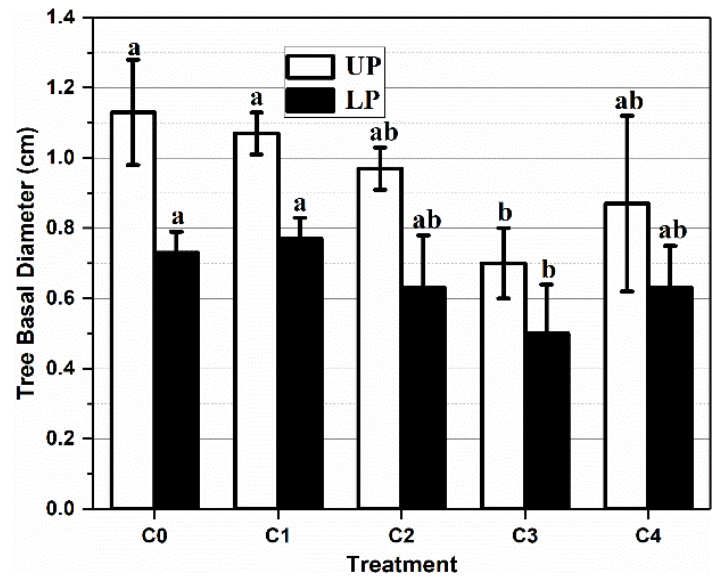

(b)

Fig. 1. Tree heights and basal diameter of UP and LP at harvest under different concentrations of Cd treatment: (a) Tree height; (b) Tree basal diameter; [Note: Average increment of tree height and basal diameter of UP and LP of three repetitions with the error bar as standard deviation $(n=3)$. The different letters $(a, b, a b)$ are significantly different based on the least significant difference test $(p<0.05)$ ] 
The inhibitory effect of heavy metal $\mathrm{Cd}$ on poplar tree height was not proportional to the concentrations of $\mathrm{Cd}$ in soil, as had been observed in a previous study by Redovnikovic et al. (2017). Similar results could be found for basal diameter for UP at all treatments and $\mathrm{LP}$ at $\mathrm{C} 2, \mathrm{C} 3$, and $\mathrm{C} 4$ treatments. The basal diameter of LP at $\mathrm{C} 1$ was even slightly larger than that at $\mathrm{C} 0$, probably indicating some promotion effect on basal diameter growth at low $\mathrm{Cd}$ treatment. Both heights and basal diameter of UP trees at harvest were larger than that of LP for all treatments (Fig. 1 (a) and (b)), indicating the inhibitory effect of leaning plantation on poplar growth. The differences of height between UP and LP were $7.24 \%$, $1.96 \%, 11.88 \%, 19.10 \%$, and $9.23 \%$, respectively, for the treatments from $\mathrm{C} 0$ to $\mathrm{C} 4$, and that of basal diameter were $23.12 \%, 14.38 \%, 16.56 \%, 20.98 \%$, and $18.75 \%$, respectively, indicating greater inhibition on basal diameter.

\section{Cd Concentration In Poplar Trees}

\section{Cd concentration in the main parts of poplar trees}

Figure 2 presents Cd concentration in the root, stem, bark, and leaf of UP and LP under different $\mathrm{Cd}$ treatments.

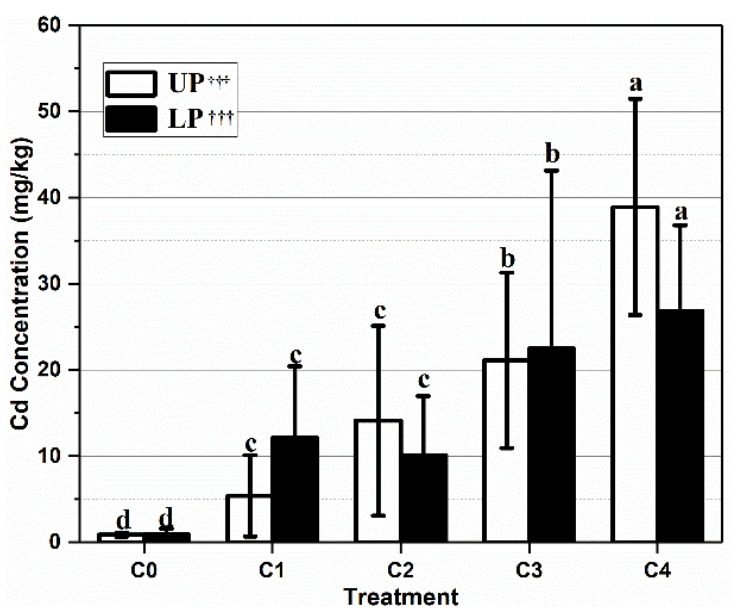

(a)

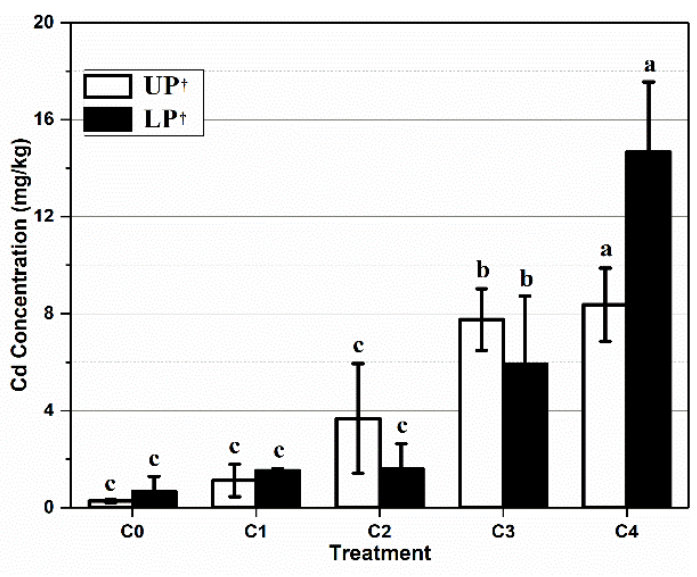

(c)

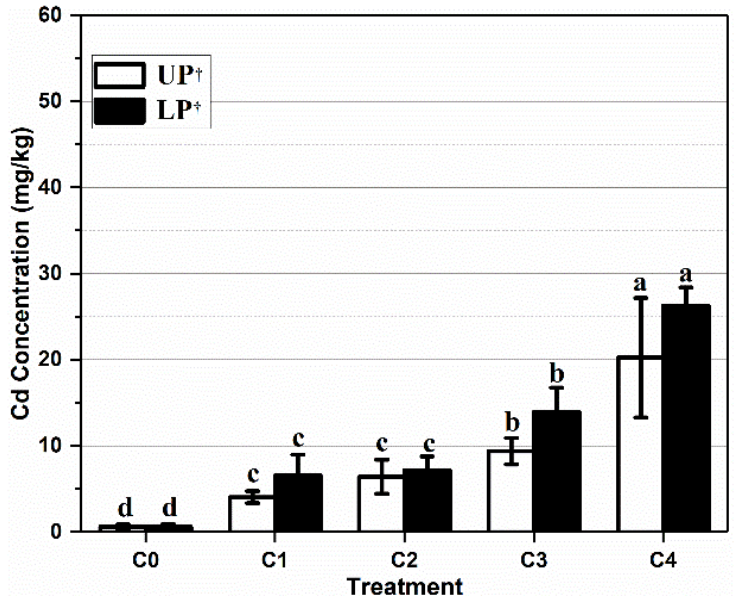

(b)

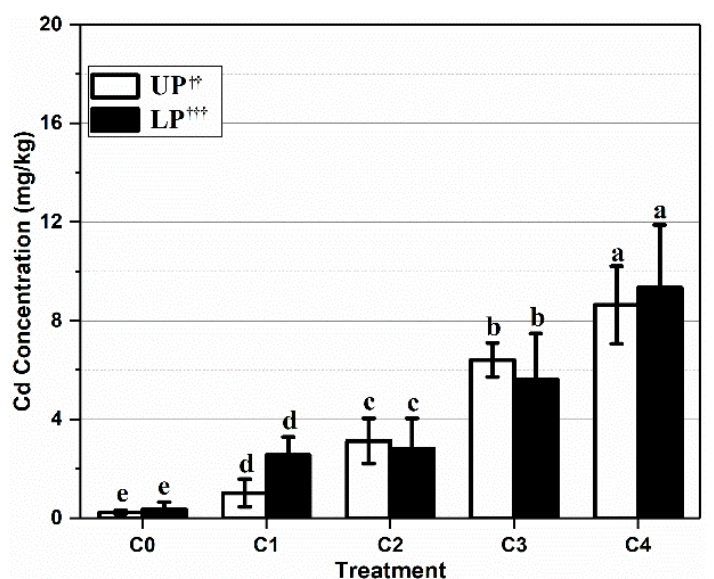

(d)

Fig. 2. Cd concentration in different parts of poplar trees: (a) Bark; (b) Leaf; (c) Root; (d) Stem; [Note: $†$ Average concentration of $\mathrm{Cd}$ in leaf or root of three repetitions with the error bar as standard deviation $(n=3)$. †† Average concentration of $\mathrm{Cd}$ in the bark or stem at three heights of three repetitions of UP with the error bar as standard deviation $(n=9)$. $\dagger \dagger \dagger$ Average concentration of $\mathrm{Cd}$ in the bark or stem in the two zones (tension zone vs opposite zone) at three heights of three repetitions of LP with the error bar as standard deviation $(n=$ 18). The different letters (a, b, c, d, and e) are significantly different based on the least significant difference test $(p<0.05)]$ 
It could be found that $\mathrm{Cd}$ concentration in different parts of poplar trees under both growth patterns increased with the treatments from $\mathrm{C} 0$ to $\mathrm{C} 4$, i.e., with the increase of $\mathrm{Cd}$ concentrations in the soil. This result was consistent with many other studies on the poplar dendroremediation of heavy metals (Robinson et al. 2000; Laureysens et al. 2004; Madejón et al. 2004; Algreen et al. 2013; Redovniković et al. 2017).

The Cd concentration in the bark and leaf were much higher than that in the root and stem, for each treatment and each growth pattern (Fig. 2). Between bark and leaf, the bark demonstrated higher $\mathrm{Cd}$ concentration than the leaf, and between root and stem, the root demonstrated higher $\mathrm{Cd}$ concentration than the stem for each treatment and each growth pattern. This result was similar with many studies in that wood contained the least among the various parts, but different from them in that they either exhibited highest levels either in leaves or in the roots, not in the barks (Laureysens et al. 2004; Unterbrunner et al. 2007; He et al. 2013; Pilipović et al. 2019). The difference in the conclusion of experiments might be related to the species and age of poplars used in the experiment, cultivation pattern, site conditions, as well as Cd stress concentration and time (Romè et al. 2015).

Through comparison between the two growth patterns, LP had higher $\mathrm{Cd}$ concentration than UP at $\mathrm{C} 1$ and $\mathrm{C} 4$ for root and stem, at $\mathrm{C} 1$ and $\mathrm{C} 3$ for the bark, and all $\mathrm{Cd}$ addition treatments for the leaf (Fig. 2). It was worth noting that the LP trees contained more $\mathrm{Cd}$ than UP in all four parts at $\mathrm{C} 1$ treatment. The LP had a higher average Cd concentration of all treatments than UP in the root, stem, and leaf, but not in the bark.

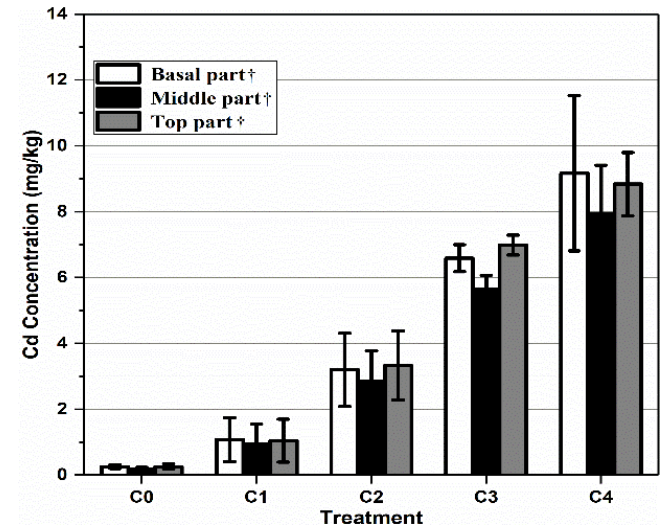

(a)

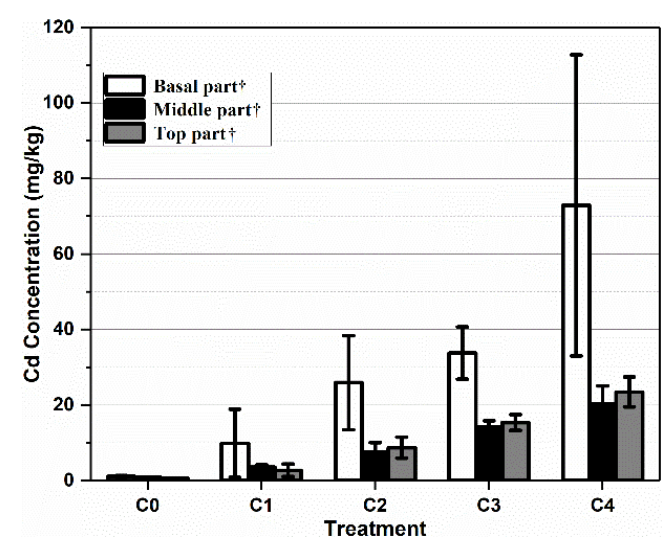

(c)

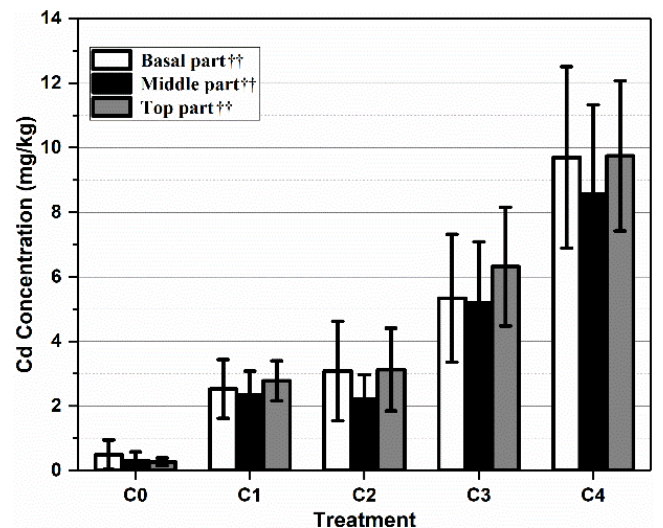

(b)

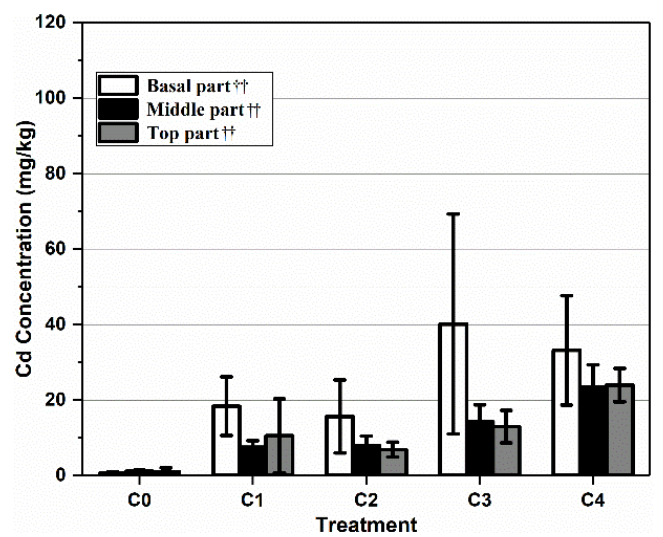

(d)

Fig. 3. Cd concentration in the stems and barks of poplar trees along the height: (a) Stem of UP; (b) Stem of LP; (c) Bark of UP; (d) Bark of LP. Note: † Average concentration of Cd in stem or bark of a certain height of UP of three repetitions with the error bar as standard deviation $(n=3)$. $† \dagger$ Average content of $C d$ in the two zones of stem of a certain height of LP of three repetitions with the error bar as standard deviation $(n=6)$ 
Vertical distribution of $C d$ in the trunk parts of poplar trees

Figure 3 compares Cd concentration in the stem and bark of UP and LP along the three trunk heights, i.e., basal, middle, and top. The $\mathrm{Cd}$ contents in the bark were accordingly much higher than that in the stem for all treatments and both growth patterns along the height. It was also found that $\mathrm{Cd}$ concentration in the stem and bark increased from $\mathrm{C} 0$ to $\mathrm{C} 4$ at each height and for each growth pattern. With the exception of LP at C0, $\mathrm{Cd}$ concentration in the middle stem were slightly lower than that in the top and basal stem for both growth patterns (Fig. 3 (a) and (b)). Additionally, with the exception of LP at C0, $\mathrm{Cd}$ concentration in the bark demonstrated much higher $\mathrm{Cd}$ concentration in the basal than that in the middle and top (Fig. 3 (c) and (d)). This result was different from the vertical distribution of Cd along the trunk of Salix, where Cd increased significantly with height (Sander and Ericssion 1998). In trees, various atypical distributions of an element were observed due to different mechanisms of transport of metals and metalloids (Toppi and Gabbrielli 1999).

By comparing between the two growth patterns, the authors found that at the treatments of $\mathrm{C} 1$ and $\mathrm{C} 4, \mathrm{Cd}$ concentration in the stem at all three heights of LP were higher than that of UP, while it was opposite for the treatments of $\mathrm{C} 2$ and $\mathrm{C} 3$. The authors also found that $\mathrm{Cd}$ concentration in the bark at all three heights of LP were much higher than that of UP at $\mathrm{C} 1$ treatment, but it was not always the case for other treatments. Thus, Cd concentration in both stem and bark of LP were higher than that of UP at C1 treatment, along the three trunk heights.

\section{Cd concentration in the two trunk zones of $L P$}

Table 1 compares Cd content in the stem and bark of TZ and OZ of LP trunks. The authors also found that $\mathrm{Cd}$ concentration in both zones generally increased from $\mathrm{C} 0$ to $\mathrm{C} 4$, with an insignificant difference between $\mathrm{C} 1$ and $\mathrm{C} 2$. For the stem, $\mathrm{TZ}$ demonstrated higher $\mathrm{Cd}$ concentration than $\mathrm{OZ}$, except $\mathrm{C} 2$. For the bark, $\mathrm{TZ}$ had lower $\mathrm{Cd}$ concentration than $\mathrm{OZ}$ at $\mathrm{C} 1, \mathrm{C} 2$, and $\mathrm{C} 4$ and it was opposite at $\mathrm{C} 3$ and $\mathrm{C} 0$, with great standard deviations for both cases (Table 1).

Table 1. Cd Concentration in the Stem and Bark Parts of the Two Trunk Zones of LP Under Different Cd Treatments $(\mathrm{mg} / \mathrm{kg}$ )

\begin{tabular}{|c|c|c|c|c|}
\hline \multirow{2}{*}{ Treatment } & \multicolumn{2}{|c|}{ Stem } & \multicolumn{2}{|c|}{ Bark } \\
\hline & Tension Zone $^{\dagger}$ & Opposite Zone ${ }^{\dagger}$ & Tension Zone $^{\dagger}$ & Opposite Zone $^{\dagger}$ \\
\hline $\mathrm{CO}$ & $0.42 \pm 0.36^{d}$ & $0.28 \pm 0.27^{d}$ & $1.08 \pm 0.86^{c}$ & $0.81 \pm 0.39^{c}$ \\
\hline $\mathrm{C} 1$ & $2.91 \pm 0.67^{c}$ & $2.19 \pm 0.66^{c}$ & $10.52 \pm 6.91^{b}$ & $13.73 \pm 9.66^{b}$ \\
\hline $\mathrm{C} 2$ & $2.77 \pm 1.21^{\mathrm{c}}$ & $2.85 \pm 1.34^{\mathrm{c}}$ & $9.78 \pm 7.66^{b}$ & $10.49 \pm 6.38^{b}$ \\
\hline C3 & $6.56 \pm 1.99^{b}$ & $4.67 \pm 1.19^{b}$ & $25.18 \pm 24.99^{a}$ & $19.73 \pm 16.38^{a}$ \\
\hline C4 & $9.63 \pm 2.33^{a}$ & $9.04 \pm 2.86^{a}$ & $26.80 \pm 8.56^{a}$ & $26.96 \pm 11.68^{a}$ \\
\hline
\end{tabular}

\section{Phytoextraction Ability}

\section{$B C F$}

The BCF represents the ability of element migration in the soil-plant system and is an evaluation index reflecting the capacity of plants to absorb and transfer heavy metals or metalloids into their bodies. The higher the factor, the stronger the ability of absorbing elements in the plant. 
BCFs of all parts ranged between 0.08 and 2.36 (Tables 2, 3), which fell in the same range as in other studies on poplar but were at a relatively low level, compared with the hyperaccumulators (Zhuang et al. 2007; Algreen et al. 2013; Redovniković et al. 2017). $\mathrm{BCFs}$ generally declined from $\mathrm{C} 1$ to $\mathrm{C} 4$, with the exception of the leaf of UP at $\mathrm{C} 4$ and the root of LP. This result was consistent with the conclusion of the study by Algreen et al. (2013) and Zhang et al. (2013) that BCF values decreased with the increase of Cd concentration in soil. However, it was different from the study of poplars on purple soil and alluvial soil with low Cd treatments from 0 to $1.5 \mathrm{mg} / \mathrm{kg}$, where an increase of BCF with the increase of Cd concentration was reported (Wu et al. 2010). For both growth patterns, bark and leaf had higher BCFs than that of stem and root. The BCF of the root of LP at C2 was rather low, which might be due to the strong transport of $\mathrm{Cd}$ from the underground part to the aerial parts. $\mathrm{C} 1$ demonstrated much higher BCFs than all other three treatments, for each part and the two growth patterns, especially for LP (Table 2 and 3).

Table 2. BCF of Different Parts of UP Under Different Cd Treatments

\begin{tabular}{|c|c|c|c|c|}
\hline \multirow{2}{*}{ Treatment } & \multicolumn{4}{|c|}{ Upright Poplar } \\
\hline & $\operatorname{Root}^{\dagger}$ & Stem ${ }^{\dagger t}$ & Bark $^{\dagger \dagger}$ & Leaf $^{\dagger}$ \\
\hline $\mathrm{C} 1$ & $0.22 \pm 0.13^{\mathrm{a}}$ & $0.20 \pm 0.18^{a}$ & $1.05 \pm 1.11^{\mathrm{a}}$ & $0.79 \pm 0.13^{a}$ \\
\hline $\mathrm{C} 2$ & $0.18 \pm 0.11^{b}$ & $0.16 \pm 0.05^{b}$ & $0.70 \pm 0.55^{b}$ & $0.32 \pm 0.10^{\mathrm{b}}$ \\
\hline C3 & $0.15 \pm 0.03^{b}$ & $0.13 \pm 0.01^{b}$ & $0.42 \pm 0.20^{b}$ & $0.19 \pm 0.03^{b}$ \\
\hline $\mathrm{C} 4$ & $0.08 \pm 0.02^{b}$ & $0.09 \pm 0.02^{b}$ & $0.39 \pm 0.33^{b}$ & $0.20 \pm 0.07^{b}$ \\
\hline Average & 0.16 & 0.15 & 0.64 & 0.38 \\
\hline
\end{tabular}

Table 3. BCF of Different Parts of LP under Different Cd Treatments

\begin{tabular}{|c|c|c|c|c|}
\hline \multirow{2}{*}{ Treatment } & \multicolumn{4}{|c|}{ Leaning Poplar } \\
\cline { 2 - 5 } & Root $^{\dagger}$ & Stem $^{\dagger+t}$ & Bark $^{\text {ttt }}$ & Leaf $^{\dagger}$ \\
\hline C1 & $0.30 \pm 0.02^{\mathrm{a}}$ & $0.50 \pm 0.14^{\mathrm{a}}$ & $2.36 \pm 1.62^{\mathrm{a}}$ & $1.28 \pm 0.46^{\mathrm{a}}$ \\
\hline $\mathrm{C} 2$ & $0.08 \pm 0.05^{\mathrm{b}}$ & $0.14 \pm 0.06^{\mathrm{b}}$ & $0.50 \pm 0.34^{\mathrm{b}}$ & $0.36 \pm 0.08^{\mathrm{b}}$ \\
\hline C3 & $0.12 \pm 0.06^{\mathrm{b}}$ & $0.11 \pm 0.04^{\mathrm{b}}$ & $0.45 \pm 0.41^{\mathrm{b}}$ & $0.28 \pm 0.06^{\mathrm{b}}$ \\
\hline C4 & $0.15 \pm 0.03^{\mathrm{b}}$ & $0.09 \pm 0.03^{\mathrm{b}}$ & $0.27 \pm 0.10^{\mathrm{b}}$ & $0.26 \pm 0.02^{\mathrm{b}}$ \\
\hline Average & 0.16 & 0.21 & 0.9 & 0.55 \\
\hline
\end{tabular}

Note: $\uparrow$ Average BCF in leaf or root of three repetitions with standard deviation $(n=3)$. ††† Average BCF in the bark or stem in the two zones (tension zone vs opposite zone) at three heights of three repetitions of LP with standard deviation $(n=18)$. The same letter within columns are not significantly different according to the least significant difference test $(p<$ $0.05)$.

By comparing the BCFs between the two growth patterns, it could be found that LP demonstrated higher average absorbing ability than UP for the aerial parts (Tables 2 and 3). The BCF range of UP was between 0.08 and 1.01, with that of the stem being between 0.09 and 0.2 (Table 2), while that of LP was between 0.08 and 2.36, with that of the stem being between 0.09 and 0.5 (Table 3). It was especially worth noting that, BCFs of the 4 parts of LP had much higher BCFs than UP at C1 treatment. This result showed that LP demonstrated higher accumulation ability of $\mathrm{Cd}$ from the soil than UP, especially at lower $\mathrm{Cd}$ treatment. 


\section{$T F$}

The TF has been used to evaluate the ability of plants to translocate and accumulate heavy metals or metalloids from the underground part (root) to the above-ground parts. The higher the TF, the stronger the transport capacity of heavy metals from roots to the aerial parts.

Table 4 demonstrates that the TFs were generally greater than or close to 1 for both upright and leaning poplars, varying between 0.67 and 7.92, thus much higher than BCFs, indicating stronger transporting capacity from poplar roots to the aboveground parts, which had also been confirmed in the study of Wu et al. (2010).

Table 4. TF of Different Parts of UP and LP Under Different Cd Treatments

\begin{tabular}{|c|c|c|c|c|c|c|}
\hline \multirow{2}{*}{ Treatment } & \multicolumn{3}{|c|}{ Upright Poplar } & \multicolumn{3}{|c|}{ Leaning Poplar } \\
\hline & Stem $^{\dagger \dagger}$ & Bark $^{\dagger t}$ & Leaf $^{\dagger}$ & Stem ${ }^{t+t}$ & Bark $^{\dagger t \dagger}$ & Leaf $^{\dagger}$ \\
\hline $\mathrm{CO}$ & $\begin{array}{c}0.87 \pm \\
0.25^{c}\end{array}$ & $\begin{array}{c}3.43 \pm \\
1.18^{\mathrm{b}}\end{array}$ & $\begin{array}{c}2.24 \pm \\
0.42^{\mathrm{b}}\end{array}$ & $\begin{array}{c}0.94 \pm \\
0.82^{\mathrm{c}}\end{array}$ & $\begin{array}{c}2.78 \pm \\
3.22^{\mathrm{b}}\end{array}$ & $\begin{array}{c}1.80 \pm \\
1.50^{\mathrm{b}}\end{array}$ \\
\hline C1 & $\begin{array}{c}0.88 \pm \\
0.31^{\mathrm{c}}\end{array}$ & $\begin{array}{c}4.63 \pm \\
3.00^{\mathrm{a}}\end{array}$ & $\begin{array}{c}4.66 \pm \\
2.65^{\mathrm{a}}\end{array}$ & $\begin{array}{l}1.66 \pm \\
0.45^{\mathrm{b}}\end{array}$ & $\begin{array}{c}7.92 \pm \\
5.47^{\mathrm{a}}\end{array}$ & $\begin{array}{l}4.31 \pm \\
1.59^{\mathrm{ab}}\end{array}$ \\
\hline C2 & $\begin{array}{c}0.97 \pm \\
0.30^{\mathrm{b}}\end{array}$ & $\begin{array}{l}4.20 \pm \\
2.88^{\mathrm{ab}}\end{array}$ & $\begin{array}{l}2.02 \pm \\
0.75^{\mathrm{ab}}\end{array}$ & $\begin{array}{c}2.19 \pm \\
1.14^{\mathrm{a}}\end{array}$ & $\begin{array}{c}7.25 \pm \\
3.88^{a}\end{array}$ & $\begin{array}{c}5.54 \pm \\
2.44^{a}\end{array}$ \\
\hline C3 & $\begin{array}{c}0.84 \pm \\
0.16^{\mathrm{c}}\end{array}$ & $\begin{array}{c}2.79 \pm \\
1.50^{\mathrm{b}}\end{array}$ & $\begin{array}{l}1.21 \pm \\
0.01^{\mathrm{b}}\end{array}$ & $\begin{array}{c}1.05 \pm \\
0.40^{c}\end{array}$ & $\begin{array}{l}4.86 \pm \\
6.31^{\mathrm{ab}}\end{array}$ & $\begin{array}{c}2.60 \pm \\
0.84^{\mathrm{b}}\end{array}$ \\
\hline C4 & $\begin{array}{l}1.05 \pm \\
0.19^{\mathrm{a}}\end{array}$ & $\begin{array}{c}4.81 \pm \\
4.27^{\mathrm{a}}\end{array}$ & $\begin{array}{c}2.49 \pm \\
1.03^{\mathrm{b}}\end{array}$ & $\begin{array}{c}0.67 \pm \\
0.24^{\mathrm{c}}\end{array}$ & $\begin{array}{c}1.91 \pm \\
0.77^{\mathrm{b}}\end{array}$ & $\begin{array}{c}1.84 \pm \\
0.39^{\mathrm{b}}\end{array}$ \\
\hline Average & 0.92 & 3.97 & 2.52 & 1.3 & 4.94 & 3.22 \\
\hline \multicolumn{7}{|c|}{$\begin{array}{l}\text { Note: † Average TF in leaf of three repetitions with standard deviation }(n=3) \text {. †† Average } \\
\text { BCF in the bark or stem at three heights of three repetitions of UP with standard deviation ( } \\
=9 \text { ). ††† Average BCF in the bark or stem in the two zones (tension zone vs opposite zone) } \\
\text { at three heights of three repetitions of LP with standard deviation }(n=18) \text {. The same letter } \\
\text { within columns are not significantly different according to the least significant difference test } \\
(p<0.05) \text {. }\end{array}$} \\
\hline
\end{tabular}

With the increase of Cd concentration in the soil, the TFs of different parts of both UP and LP no longer showed a general trend of decreasing, but sometimes even increased (Table 4). This result was similar to the conclusion by Zhang et al. (2013), that TFs of poplar and willow varied irregularly with soil Cd concentrations (Redovniković et al. 2017; Wu et al. 2010). For poplar trees under both plantations, the TFs of the parts had the following orders: Bark $>$ Leaf $>$ Stem.

By comparing the TFs between the two growth patterns, it could be found that LP demonstrated higher average TFs than UP, with the TFs of the leaf, the bark, and the stem of LP being $27.8 \%, 24.4 \%$, and $41.3 \%$ larger than that of UP, respectively. The TF range of UP was between 0.84 and 4.81 , with that of the stem being between 0.84 and 1.05 , while that of LP was between 0.67 and 7.92, with that of the stem being between 0.67 and 2.19 (Table 4). The TFs of the stem and the bark of LP were much higher than that of UP at C1, $\mathrm{C} 2, \mathrm{C} 3$, but not at $\mathrm{C} 0$ and $\mathrm{C} 4$. This result showed that $\mathrm{LP}$ demonstrated higher translocation ability of $\mathrm{Cd}$ from root to the trunk than UP, except the very high $\mathrm{Cd}$ treatment $(\mathrm{C} 4)$ and the very low control group.

\section{Discussion}

\section{Tolerance of poplar to Cd stress}

Sapling growth has often been used to evaluate tree response to exogenous stress, with their greater sensitivity to adverse conditions than mature trees (Pulford and Watson 2003). In this study height and diameter of tree saplings were measured to investigate the influence of Cd stress, as well as leaning plantation, on poplar growth. The authors' result 
demonstrated that $\mathrm{Cd}$ addition significantly inhibited poplar growth (Fig. 1 (a) and (b)), but the inhibitory effect was not proportional to the concentrations of $\mathrm{Cd}$ in soil and there might even be some promotional effect on basal diameter at low Cd treatment (Fig. 1). Both UP and LP can grow under Cd stress until at treatment with $\mathrm{Cd}$ addition as high as $100 \mathrm{mg} / \mathrm{kg}$ and $\mathrm{Cd}$ accumulation in various parts of poplars all increased with the increase of $\mathrm{Cd}$ addition in the soil, indicating strong Cd tolerance of poplars to heavy metal $\mathrm{Cd}$ and relatively considerable phytoextraction ability of poplar even at high $\mathrm{Cd}$ stress. The authors' previous study on poplar trees growing on the floodplain downstream a mining hill, which was polluted by $\mathrm{Cu}, \mathrm{Zn}, \mathrm{Cd}$, and $\mathrm{As}$, with $\mathrm{Cd}$ in the soil being approximately $10 \mathrm{mg} / \mathrm{kg}$, showed that poplars can grow quite well at those concentration levels until 20 to $30 \mathrm{~m}$, reaching their full growth (Kataweteetham et al. 2020). The strong tolerance ability of poplar to $\mathrm{Cd}$ stress makes it a promising species for the recovery of polluted regions, especially in the remediation and utilization of highly polluted land.

In terms of pollution control practice, considering the phytoextraction ability of poplar, its strong tolerance to heavy metals, and its considerable growth rate and biomass, poplar could be recommended as a species that can be planted in a variety of contaminated sites for pollution treatment purpose.

\section{Inhabitation of leaning plantation on poplar growth}

Although both Cd stress and leaning plantation had a significant influence on poplar growth (Table 5), leaning plantation had a more inhibitory effect on poplar growth, resulting in considerably lower height and basal diameter of LP than that of UP, especially at higher $\mathrm{Cd}$ treatments. In the formation of tension wood, a dissymmetrical distribution of growth stresses capable to modify the orientation of different axes in space caused the shrinkage of the gelatinous layer, resulting in high macroscopic longitudinal contraction observed in tension wood (Jourez 1997; Clair and Thibaut 2001).

\section{Comparison between UP and LP in the accumulation of $C d$}

For both UP and LP, bark and leaf absorb a considerate amount of Cd than stem and root. This demonstrated strong transportation of $\mathrm{Cd}$ from underground parts to the top parts and the bark played important role in the transportation, probably through welldeveloped vessels during the transpiration process. This high transportation was confirmed by the TFs of bark and leaf, demonstrating the importance of the strong transpiration effect of broad-leaved trees, such as poplars. Besides, materials such as terpenoids, suberin, fatty acid esters, parenchyma cells, etc., which are rich in the bark tissues would probably help bind the divalent ions. In addition, some amino acids in bark combine with divalent $\mathrm{Cd}$ ions to form metal-binding peptides (Satofuka et al. 2001). However, only a limited amount of Cd was accumulated in the stem wood tissues, where they are expected to be the best storage place for heavy metals because of the great biomass.

By comparing $\mathrm{Cd}$ accumulation of poplars between the upright and leaning plantations, LP demonstrated higher mean concentrations of $\mathrm{Cd}$ in various parts in general and in the trunk parts along the heights, and stronger phytoextraction ability in terms of BCF and TF than that of UP, but all did not reach a significant level (Table 5). This difference was greater in the $\mathrm{TZ}$ of $\mathrm{LP}$, which might be due to the large number of microvoids in $\mathrm{TZ}$ that played an important role in the adsorption and fixation of $\mathrm{Cd}$ (Liu and Liu 2011; Chang et al. 2015). The LP at C1 treatment (5 mg/kg Cd addition) was highlighted for generally higher Cd content, BCFs, and TFs than UP and LP at other treatments, especially for the trunk parts. 
Table 5. Multi-way ANOVA Analysis on Cd Concentration in Poplar, BCF, and TF Under Different Cd Treatments, in Different Parts, and Between the Two Growth Patterns ( $P$ value)

\begin{tabular}{|c|c|c|c|c|c|c|c|c|}
\hline \multirow[t]{2}{*}{ Factors } & \multirow{2}{*}{$\begin{array}{c}\text { Basal } \\
\text { Diameter }\end{array}$} & \multirow{2}{*}{$\begin{array}{l}\text { Cd in } \\
\text { Parts }\end{array}$} & \multicolumn{2}{|c|}{$\begin{array}{c}\text { Cd Along } \\
\text { Heights }\end{array}$} & \multicolumn{2}{|c|}{ Cd in Zones } & \multirow[t]{2}{*}{ BCF } & \multirow[t]{2}{*}{ TF } \\
\hline & & & Stem & Bark & Stem & Bark & & \\
\hline $\begin{array}{c}\text { Cd treatments } \\
(\mathrm{T})\end{array}$ & 0.008 & $<0.001$ & $<0.001$ & $<0.001$ & $<0.001$ & $<0.001$ & $<0.001$ & 0.002 \\
\hline $\begin{array}{c}\text { Parts } \\
\text { /Heights/Zones } \\
(\mathrm{P})\end{array}$ & I & $<0.001$ & 0.105 & $<0.001$ & 0.046 & 0.894 & $<0.001$ & $\begin{array}{c}< \\
0.001\end{array}$ \\
\hline $\begin{array}{c}\text { Growth } \\
\text { patterns (GP) }\end{array}$ & $<0.001$ & 0.682 & 0.355 & 0.399 & I & I & 0.147 & 0.096 \\
\hline$T^{*} P$ & 1 & $<0.001$ & 0.942 & 0.001 & 0.352 & 0.856 & $<0.001$ & 0.305 \\
\hline$T$ * GP & 0.005 & 0.884 & 0.061 & 0.031 & I & I & 0.041 & 0.027 \\
\hline$P^{*} G P$ & I & 0.62 & 0.955 & 0.119 & I & I & 0.572 & 0.705 \\
\hline$T^{*} P^{*} G P$ & l & 0.472 & 1 & 0.018 & I & I & 0.186 & 0.359 \\
\hline
\end{tabular}

Based on the above findings, LP had only slightly stronger Cd accumulation ability than UP for the 1-year-old poplars. However, a continuous comparison study might be worth conducting to track a longer life cycle of poplar growth under Cd stress, especially with a special focus on the $\mathrm{C} 1$ treatment. Further study might also be focused on cell and cell wall level to understand the mechanism of phytoextraction of $\mathrm{Cd}$ by poplar and on the following promotion efforts to increase phytoextraction ability and to promote the accumulation in the stem.

\section{CONCLUSIONS}

1. The inhibitory effect of $\mathrm{Cd}$ addition on poplar growth was significant, and the inhibitory effect was not proportional to the concentrations of $\mathrm{Cd}$ in soil. Despite the inhibition effect, both upright poplar (UP) and leaning poplar (LP) can grow until at the treatment with $100 \mathrm{mg} / \mathrm{kg} \mathrm{Cd}$ addition, indicating strong tolerance of poplar to $\mathrm{Cd}$ stress. Leaning plantation also inhibited tree growth in terms of height and basal diameter, especially at higher $\mathrm{Cd}$ addition treatments.

2. Cd concentrations in various tissues increased generally with the increase of $\mathrm{Cd}$ in the soil for both UP and LP. The highest Cd was accumulated in the above ground parts of transpiration, i.e. the bark or the leaf. $\mathrm{Cd}$ in the wood part of the stem was always the lowest. Cd concentrations followed a general order as Bark $>$ Leaf $>$ Root $>$ Stem for the one-year-old poplars. Along the trunk height, the largest $\mathrm{Cd}$ content was in the top for the stem, but in the basal for the bark.

3. Different parts of poplar demonstrated average BCFs ranges between 0.08 to 2.36, and average TFs between 0.67 to 7.92 , indicating the big difference in phytoextraction ability among the parts, among the treatments, and between the two plantations. Bark or leaf had the highest BCF and TF, while that of the branch and stem were the lowest, indicating poor phytoextraction ability in wood parts. BCFs declined with the increase 
of $\mathrm{Cd}$ addition in the soil, but the change of TF was not proportional to Cd levels in the soil. At C1 treatment with low $\mathrm{Cd}$ addition, poplar demonstrated much higher BCF than all other three treatments, for each part, especially for LP.

4. Average $\mathrm{Cd}$ concentrations in the various parts in general and in the bark and stem along the heights of LP, as well as average BCF and TF for each part of LP were higher than that of UP, but the difference was not significant. Significantly higher Cd concentration was found in the TZ of stem wood than that in the OZ for LP. Thus, leaning plantation limited poplar growth but only slightly promoted $\mathrm{Cd}$ accumulation in poplar tissues.

\section{ACKNOWLEDGMENTS}

Author contributions: S. L. and Y. C. conceived and designed the experiment; G. R., L. K., and J. Z. completed the experiment; G. R. and Y. C. analyzed the experimental data; G. R. wrote the first draft; Y. C. translated and reviewed the paper.

This work was supported by the National Natural Science Foundation of China (31770595). The authors are grateful to Haiyan Chen, Di Zhang, and Shuyun Yang for their help with the experiment. The authors declare no conflict of interest.

\section{REFERENCES CITED}

Algreen, M., Trapp, S., and Rein, A. (2013). "Phytoscreening and phytoextraction of heavy metals at Danish polluted sites using willow and poplar trees," Environmental Science Pollution Research 21(15), 8992-9001. DOI: 10.1007/s11356-013-2085-z

Ali, H., Khan, E., and Sajad, M. A. (2013). "Phytoremediation of heavy metals--concepts and applications," Chemosphere 91(7), 869-881. DOI: 10.1016/j.chemosphere.2013.01.075

Antony, V. D. E., Baker, A. J. M., Reeves, R. D., Pollard, A. J., and Schat, H. (2012). "Hyperaccumulators of metal and metalloid trace elements: Facts and fiction," Plant and Soil 362(1-2), 319-334. DOI: 10.1007/s11104-012-1287-3

Archer, R. R. (1987). Growth Stresses and Strains in Trees, Springer, Berlin, Germany. DOI: 10.1007/978-3-662-02511-6

Azzarello, E., Pandolf, C., Pollastri, S., Masi, E., Mugnai, S., and Mancuso, S. (2011). "The use of trees in phytoremediation," CAB Reviews Perspectives in Agriculture, Veterinary Science, Nutrition and Natural Resources 6(37), 1-15. DOI: 10.1079/PAVSNNR20116037

Chang, S. S., Quignard, F., Almeras, T., and Clair, B. (2015). "Mesoporosity changes from cambium to mature tension wood: A new step toward the understanding of maturation stress generation in trees," New Phytologist 205, 1277-1287. DOI; 10.1111/nph. 13126

Clair, B., and Thibaut, B. (2001). "Shrinkage of the gelatinous layer of poplar and beech tension wood," IAWA Journal 22(2), 121-131. DOI: 10.1163/22941932-90000273

CNEMC and SEPA (1990). Background Values of Soil Elements in China, China Environmental Science Press, Beijing, China.

Escarré, J., Lefèbvre, C., Raboyeau, S., Dossantos, A., Gruber, W., Marel, J. C. C., Frérot, H., Noret, N., Mahieu, S., Collin, C., et al. (2011). "Heavy metal concentration survey in soils and plants of the Les Malines mining district (Southern 
France): Implications for soil restoration," Water Air Soil Pollution 216(1-4), 485504. DOI: $10.1007 / \mathrm{s} 11270-010-0547-1$

Fang, C. H., Clair, B., Gril, J., and Liu, S. Q. (2008). "Growth stresses are highly controlled by the amount of G-layer in poplar tension wood," IAWA Journal 29(3), 237-246. DOI: 10.1163/22941932-90000183

Fisher, J. B., and Stevenson, J. W. (1981). "Occurrence of reaction wood in branches of dicotyledons and its role in tree architecture," Botanical Gazette 142(1), 82-95. DOI: $10.1086 / 337199$

Fuksová, Z., Száková, J., and Tlustoš, P. (2009). "Effects of co-cropping on bioaccumulation of trace elements in Thlaspi caerulescens and Salix dasyclados," Plant Soil and Environment 55(11), 461-467. DOI: 10.17221/42/2009-PSE

GB 15618 (2018). "Soil environmental quality: Risk control standard for soil contamination of agricultural land," Standardization Administration of China, Beijing, China.

González-Oreja, J. A., Rozas, M. A., Alkorta, I., and Garbisu, C. (2008). "Dendroremediation of heavy metal polluted soils," Reviews on Environmental Health 23(3), 1-12. DOI: 10.1515/REVEH.2008.23.3.223

Han, F. X., Banin, A., Su, Y., Monts, D. L., Plodinec, M. J., Kingery, W. L., and Triplett, G. E. (2002). "Industrial age anthropogenic inputs of heavy metals into the pedosphere," Naturwissenschaften 89(11), 497-504. DOI: 10.1007/s00114-002-0373-4

He, J. L., Ma, C. F, Ma, Y. H., Li, H., Kang, J. Q., Liu, T. X., Polle, A., Peng, C. H., and Luo, Z. B. (2013). "Cadmium tolerance in six poplar species," Environmental Science and Pollution Research 20(1), 163-174. DOI: 10.1007/s11356-012-1008-8

Jourez, B. (1997). "Le bois de tension. 1. Définition et distribution dans l'arbre [Tention wood. 1. Definition and distribution in trees]," Biotechnologie. Agronomie. Société et Environnement [Biotechnology, Agronomy, Society and Environment] 1(2), 100-112. DOI: $10.2516 /$ ogst:1984036

Kataweteetham, L., Rong, G., Zhu, J., Chu, Y., and Liu, S. Q. (2020). "Dendroremediation of metal and metalloid elements with poplar and willow in the floodplain area downstream a mining hill, Tongling, China," IOP Conference Series: Earth and Environmental Science 453, Article ID 012026. DOI: 10.1088/17551315/453/1/012026

Laureysens, I., Blust, R., Temmerman, L. D., Lemmens, C., and Ceulemans, R. (2004). "Clonal variation in heavy metal accumulation and biomass production in a poplar coppice culture: I. Seasonal variation in leaf, wood and bark concentrations," Environmental Pollution 131(3), 485-494. DOI: 10.1016/j.envpol.2004.02.009

Li, J. T., Baker, A. J. M., Ye, Z. H., Wang, H. B., and Shu, W. S. (2012). "Phytoextraction of Cd-contaminated soils: Current status and future challenges," Critical Reviews in Environmental Science and Technology 42(20), 2113-2152. DOI: 10.1080/10643389.2011.574105

Liu, Y. M., and Liu, S. Q. (2011). "Microfibril angle, basic density and longitudinal shrinkage of different inclined angles in artificial leaned saplings of poplar ' I -107' (Populus $\times$ euramericana 'Neva')," Scientia Silvae Sinicae 47(8), 115-120. DOI: 10.11707/j.1001-7488.20110818

Madejón, P., Marañón, T., Murillo, J. M., and Robinson, B. (2004). "White poplar (Populus alba) as a biomonitor of trace elements in contaminated riparian forests," Environmental Pollution 132(1), 145-155. DOI: 10.1016/j.envpol.2004.03.015

Mahar, A., Wang, P., Ali, A., Awasthi, M. K., Lahori, A. H., Wang, Q., Li, R. H., and Zhang, Z. Q. (2016). "Challenges and opportunities in the phytoremediation of heavy metals contaminated soils: A review," Ecotoxicology and Environmental Safety 126, 111-121. DOI: 10.1016/j.ecoenv.2015.12.023 
McLaughlin, M. J., Parker, D. R., and Clarke, J. M. (1999). "Metals and micronutrients food safety issues," Field Crops Research 60(1-2), 143-163. DOI: 10.1016/S03784290(98)00137-3

Parrotta, L., Guerriero, G., Sergeant, K., Cai, G., and Hausman, J. F. (2015). "Target or barrier? The cell wall of early-and later-diverging plants $v s$. cadmium toxicity: Differences in the response mechanisms," Frontiers in Plant Science 6(133), 1-17. DOI: $10.3389 /$ fpls.2015.00133

Pilipović, A., Zalesny, Jr., R. S., Rončević, S., Nikolić, N., Orlović, S., Beljin, J., and Katanić, M. (2019). "Growth, physiology, and phytoextraction potential of poplar and willow established in soils amended with heavy-metal contaminated, dredged river sediments," Journal of Environmental Management 239, 352-365. DOI: 10.1016/j.jenvman.2019.03.072

Pulford, I. D., and Watson, C. (2003). "Phytoremediation of heavy metal-contaminated land by trees - A review," Environment International 29(4), 529-540. DOI: 10.1016/S0160-4120(02)00152-6

Redovniković, I. R., Marco, A. D., Proietti, C., Hanousek, K., Sedak, M., Bilandžić, N., and Jakovljević, T. (2017). "Poplar response to cadmium and lead soil contamination," Ecotoxicology and Environmental Safety 144, 482-489. DOI: 10.1016/j.ecoenv.2017.06.011

Robinson, B. H., Mills, T. M., Petit, D., Fung, L. E., Green, S. R., and Clothier, B. E. (2000). "Natural and induced cadmium-accumulation in poplar and willow: Implications for phytoremediation," Plant and Soil 227(1-2), 301-306. DOI: 10.1023/A:1026515007319

Romè, C., Romeo, S., Francini, A., Andreucci, A., and Sebastiani, L. (2015). "Leaves position in Populus alba Villafranca clone reveals a strategy towards cadmium uptake response," Plant Growth Regulation 79(3), 355-366. DOI:10.1007/s10725-015-0139-6

Sander, M. L., and Ericssion, T. (1998). "Vertical distributions of plant nutrients and heavy metals in Salix viminalis stems and their implications for sampling," Biomass and Bioenergy 14(1), 57-66. DOI: 10.1016/S0961-9534(97)10004-6

Satofuka, H., Fukui, T., Takagi, M., Atomi, H., and Imamaka, T. (2001). "Metal-binding properties of phytochelatin-related peptides," Journal of Inorganic Biochemistry 86, 595-602. DOI: 10.1016/S0162-0134(01)00223-9

Thakur, S., Singh, L., Wahid, A. Z., Siddiqui, M. F., Atnaw, S. M., and Din, M. F. M. (2016). "Plant-driven removal of heavy metals from soil: Uptake, translocation, tolerance mechanism, challenges, and future perspectives," Environmental Monitoring and Assessment 188(206), 1-11. DOI: 10.1007/s10661-016-5211-9

Toppi, L. S. D., and Gabbrielli, R. (1999). "Response to cadmium in higher plants," Environmental and Experimental Botany 41(2), 105-130. DOI: 10.1016/S00988472(98)00058-6

Unterbrunner, R., Puschenreiter, M., Sommer, P., Wieshammer, G., Tlustos, P., Zupan, M., and Wenzel, W. W. (2007). "Heavy metal accumulation in trees growing on contaminated sites in Central Europe," Environmental Pollution 148(1), 107-114. DOI: 10.1016/j.envpol.2006.10.035

Wang, X., and Jia, Y. F. (2010). "Study on adsorption and remediation of heavy metals by poplar and larch in contaminated soil," Environmental Science and Pollution Research 17(7), 1331-1338. DOI: 10.1007/s11356-010-0313-3

Wu, F. Z., Yang, W. Q., Zhang, J., and Zhou, L. Q. (2010). "Cadmium accumulation and growth responses of a poplar (Populus deltoides $\times$ Populus nigra) in cadmium contaminated purple soil and alluvial soil," Journal of Hazardous Materials 177(1-3), 268-273. DOI: 10.1016/j.jhazmat.2009.12.028 
Zeng, P., Guo, Z. H., Xiao, X. Y., Peng, C., Feng, W. L., Xin, L. Q., and Xu, Z. (2019). "Phytoextraction potential of Pteris vittata L. co-planted with woody species for As, $\mathrm{Cd}, \mathrm{Pb}$ and $\mathrm{Zn}$ in contaminated soil," Science of The Total Environment 650(Part 1), 594-603. DOI: 10.1016/j.scitotenv.2018.09.055

Zhang, C. Y., Wang, R. G., Fan, Z. L., Shi, S. Z., Ding, Y. Z, Guo, J. K., and Zhao, Y. J. (2013). "Difference in cadmium, zinc and lead accumulation of poplar and willow species," Journal of Agro-Environment Science 32(3), 530-538. DOI: 10.11654/jaes.2013.03.019

Zhang, P. Y., Qin, C. Z., Hong, X., Kang, G. H., Qin, M. Z., Yang, D., Pang, B., Li, Y. Y., He, J. J., and Dick, R. P. (2018). "Risk assessment and source analysis of soil heavy metal pollution from lower reaches of Yellow River irrigation in China," Science of The Total Environment 633, 1136-1147. DOI: 10.1016/j.scitotenv.2018.03.228

Zhuang, P., Yang, Q. W., Wang, H. B., and Shu, W. S. (2007). "Phytoextraction of heavy metals by eight plant species in the field," Water Air and Soil Pollution 184(1-4), 235-242. DOI: 10.1007/s11270-007-9412-2

Article submitted: December 28, 2020; Peer review completed: February 21, 2021;

Revisions accepted: March 5, 2021; Published: March 23, 2021.

DOI: 10.15376/biores.16.2.3422-3436 